\title{
Correction to: Transient receptor potential ankyrin 1 promoter methylation and peripheral pain sensitivity in Crohn's disease
}

\author{
Sara Gombert ${ }^{*}$ (10, Mathias Rhein ${ }^{1}$, Andreas Winterpacht ${ }^{2}$, Tino Münster ${ }^{3,4}$, Thomas Hillemacher ${ }^{1,5}$, \\ Andreas Leffler ${ }^{6}$ and Helge Frieling ${ }^{1}$
}

\section{Correction to: Clinical Epigenetics (2020) 12:1 https://doi.org/10.1186/s13148-019-0796-9}

Following publication of the original article [1], an error was identified in the use of reference 42 which was cited insufficiently. Data of healthy participants, which were used for comparison with the Crohn patient group in figures 1, 2, 4 and 5, and table 2, were already analyzed and published previously in:

42. Gombert S, Rhein $M$, Eberhardt M, Munster T, Bleich S, Leffler A, et al. Epigenetic divergence in the TRPA1 promoter correlates with pressure pain thresholds in healthy individuals. Pain. 2017;158(4):698-704. Epub 2016/12/29.
Germany. ${ }^{6}$ Department of Anesthesiology and Intensive Care Medicine, Hannover Medical School, Hannover, Germany.

Published online: 30 March 2021

\section{Reference}

1. Gombert S, Rhein M, Winterpacht A, Münster T, Hillemacher T, Leffler A, Frieling H. Transient receptor potential ankyrin 1 promoter methylation and peripheral pain sensitivity in Crohn's disease. Clin Epigenet. 2020;12:1. https://doi.org/10.1186/S13148-019-0796-9.

\section{Publisher's Note}

Springer Nature remains neutral with regard to jurisdictional claims in published maps and institutional affiliations.

\begin{abstract}
Author details
${ }^{1}$ Laboratory for Molecular Neuroscience, Department of Psychiatry, Socialpsychiatry and Psychotherapy, Hannover Medical School, Feodor-Lynen-Str. 35, 30625 Hannover, Germany. ${ }^{2}$ Institute of Human Genetics, Friedrich-Alexander University Erlangen-Nuremberg, Erlangen, Germany. ${ }^{3}$ Department of Anesthesiology, Friedrich-Alexander University Erlangen-Nuremberg, Erlangen, Germany. ${ }^{4}$ Clinic for Anesthesiology and Critical Care, Hospital of the Order of St. John of God Regensburg, Regensburg, Germany. ${ }^{5}$ Department of Psychiatry and Psychotherapy, Paracelsus Medical University Nuremberg, Nuremberg,
\end{abstract}

The original article can be found online at https://doi.org/10.1186/s13148019-0796-9.

*Correspondence: Gombert.Sara@mh-hannover.de

${ }^{1}$ Laboratory for Molecular Neuroscience, Department of Psychiatry,

Socialpsychiatry and Psychotherapy, Hannover Medical School,

Feodor-Lynen-Str. 35, 30625 Hannover, Germany

Full list of author information is available at the end of the article

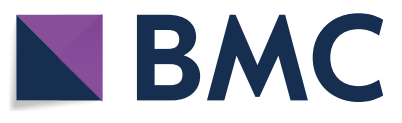

(c) The Author(s) 2021. This article is licensed under a Creative Commons Attribution 4.0 International License, which permits use, sharing, adaptation, distribution and reproduction in any medium or format, as long as you give appropriate credit to the original author(s) and the source, provide a link to the Creative Commons licence, and indicate if changes were made. The images or other third party material in this article are included in the article's Creative Commons licence, unless indicated otherwise in a credit line to the material. If material is not included in the article's Creative Commons licence and your intended use is not permitted by statutory regulation or exceeds the permitted use, you will need to obtain permission directly from the copyright holder. To view a copy of this licence, visit http://creativecommons.org/licenses/by/4.0/. The Creative Commons Public Domain Dedication waiver (http://creativecommons.org/publicdomain/zero/1.0/) applies to the data made available in this article, unless otherwise stated in a credit line to the data. 